\title{
Three Paintings by Egon Schiele: Ideas About the Essence of Art
}

\author{
Ksenia V. Reznikova, Alexandra A. Sitnikova \\ and Yulia S. Zamaraeva \\ Siberian Federal University \\ 79 Svobodny, Krasnoyarsk, 660041, Russia
}

Received 09.06.2019, received in revised form 04.07.2019, accepted 10.07.2019

Egon Schiele (1890-1918) is one of the most significant representatives of Austrian expressionism, whose works influenced not only numerous painters and graphic artists, but dancers and theatrical stage employees as well. However, few academic publications are devoted to E. Schiele's creative work, and among the existing ones, there is a significant proportion of those where his paintings are considered as the evidence of deviations in the painter's mental health. The main method used in the present work is the philosophical and art studies analysis, appealing to the universal meanings of works of art. Three paintings: Self-Portrait with Black Vase (1911), The Holy Family (1913) and Death and the Maiden (1915), which can be combined into one series demonstrating the genesis of Egon Schiele's ideas about art in general and about his creative work in particular, are the material for this study.

Keywords: Egon Schiele, expressionism, turn of the 19th-20th centuries, G. Klimt, Vienna, self-portrait.

Research area: theory and history of culture.

Citation: Reznikova, K.V., Sitnikova, A.A., Zamaraeva, Yu.S. (2019). Three paintings by Egon Schiele: ideas about the essence of art. J. Sib. Fed. Univ. Humanit. soc. sci., 12(7), 1240-1255. DOI: $10.17516 / 1997-1370-0451$.

\section{Introduction}

As a rule, modern art studies are of interdisciplinary nature. The main purpose of these studies is to identify hidden senses and meanings in the signs of artworks. Semiotic analysis of artworks originated in the $19^{\text {th }}$ century, distributed in the humanities research of the $20^{\text {th }}$ century and does not require special grounding in the $21^{\text {st }}$ century (Seredkina, 2015). In addition to the semiotic analysis of literary (Kolesnik, 2016),

(C) Siberian Federal University. All rights reserved

* Corresponding author E-mail address: decanka@mail.ru ORCID: 0000-0003-1299-6741 (Zamaraeva); 0000-0002-1622-2797 (Sitnikova)

This work is licensed under a Creative Commons Attribution-NonCommercial 4.0 International License (CC BY-NC 4.0). 
musical (Lozinskaya, 2018; Metlyaeva, 2017), architectural (Kistova, \& Tamarovskaya, 2015) and artistic works (Kolesnik et al.; Leshchinskaya, \& Petrova, 2019), the theory of art turns to culturology as a science that combines deep conceptual studies and a specific analysis of cultural phenomenon in its historical dynamics. National theory and history of culture combines various scientific disciplines, including religious studies, ethnic studies, anthropological studies, gender studies and a number of others (Kistova et al., 2016; Reznikova, et al., 2016). Such an integrated approach gives an opportunity to consider a cultural phenomenon in its dynamics on the one hand, and in the aspect of its ideological significance for a certain stage in the history of culture on the other hand.

The authors of the present paper proceed from the fact that creative work of a great artist is an expression of the main ideas of the era contemporary to an artist in visual signs and images. The interest of humanitarian researchers in recent years is turned to the phenomenon of Viennese Modernism, since amazing cultural processes that have a radical impact on the whole world, on the Eurasian and American continents, emerge there.

Egon Schiele (1890-1918) is one of the most significant representatives of Austrian expressionism, whose works influenced not only a lot of painters and graphic artists, but dancers and theatrical stage employees as well. At the same time, E. Schiele's paintings are often studied as visualization of mental disorders. And this tendency makes the philosophical and art studies analysis of his paintings relevant, sufficiently leveling the author's personal component and to a greater extent appealing to the universal meanings of his works of art. Three paintings by E. Schiele: Self-Portrait with Black Vase (1911), The Holy Family (1913) and Death and the Maiden (1915) are to be studied in the present paper.

\section{Theoretical framework}

There are quite a few academic publications devoted to E. Schiele's creative work, and among the existing ones there is a significant amount of those where his works are considered as evidence of deviations in the artist's mental health, and he is considered as the "psychotic artist" (Resnik, 2000; Izenberg, 2006; Blackshaw, 2007; Erbguth, 2010; Buckley, 2012; Kharseyeva, Godal, 2017). K.A. Smith analyzes the Austrian artist's works in terms of reflecting Kant's, Nietzsche's, as well as expressionism ideas in them (Smith, 2000). For D.F. de Oliveira E. Schiele's self-portraits are visualization of the archetype of Trickster (de Oliveira, 2012). 
Creative work of E. Schiele as one of the prominent representatives of expressionism is studied by S.M. Lam and G. Vittory (Lam, 2003; Vittory, 2018), with G. Vittory studying not only pictorial, but also choreographic contribution of E. Schiele to expressionism, referring to the phenomenon of combining painting with acting and dance.

F.J. Erbguth pays special attention to the poses of the characters depicted by E. Schiele, and S. Resnik to their hands. G. N. Izenberg considers E. Schiele's internal conflicts, which were reflected in his paintings, as an interpretation of the crisis of masculinity in Europe at the turn of the $19^{\text {th }}$ and $20^{\text {th }}$ centuries (Izenberg, 2006). G. Blackshaw also broadens the context of E. Schiele's paintings and connects it with the interest and relevance of the pathological body to the culture of Vienna at the turn of centuries (Blackshaw, 2007). R. Heller and P.J. Buckley add E. Schiele along with G. Klimt to the Golden Age of Vienna into the context of the turn of the $19^{\text {th }}-20^{\text {th }}$ centuries (Heller, 1977; Buckley, 2012).

The self-portraits by E. Schiele (Knafo, 1991; Izenberg, 2006; Blackshaw, 2007; de Oliveira, 2012), as well as portraits of young people (Borowitz, 1974; Erbguth, 2010) are of the greatest interest as a material for analysis. K. A. Smith and G. Barker actualize the theme of landscape that is quite rare in E. Schiele's creative work (Smith, 2000; Barker, 2003). The fate of individual paintings by E. Schiele, as well as individual collections of his paintings are studied by S.E. Brabenec, C. Aguado, S. Bueno and M. Pilar (Brabenec, 2001; Aguado, 2011; Bueno, Pilar, 2012).

The main method used in the present study is philosophical and art study analysis, the main provisions of which were developed by V.I. Zhukovskiy, N.P. Koptseva and D.V. Pivovarov and outlined in a number of publications (Zhukovskiy, 2008a; Zhukovskiy, 2008b; Koptseva, Zhukovskiy, 2008; Zhukovskiy, Pivovarov, 2012; Zhukovskiy, 2014). Approbation of the philosophical and art study analysis was carried out on the material of architectural works (Sitnikova, Zhukovskiy, 2018; Koptseva, 2018), paintings (Kistova, et al, 2016; Koptseva, 2014; Koptseva, Reznikova, 2015), applied and decorative arts of indigenous peoples of the North (Libakova et al., 2017; Kistova, Pimenova, Bukova, 2018), pieces of visual advertising (Bralkova et al., 2015; Koptseva, Reznikova, 2017), religious art, etc.

\section{Analysis of three paintings by E. Schiele}

Hereafter, we turn to the analysis of three paintings by Egon Schiele: Self-Portrait with Black Vase (1911), The Holy Family (1913) and Death and the Maiden (1915). 
Self-Portrait with Black Vase, 1911, 27.5 x $34 \mathrm{~cm}$, oil on wood. Art History Museum, Vienna, Austria (Fig. 1)

In the painting of a horizontal format there is a man occupying the left half of it. Black color dominates in his image: in his clothes, eyes, eyebrows and short hair. The hand and the wrist of his left arm are depicted in the upper right side of the man's chest, in the area of his shoulder and neck against the background of black clothes. The depicted part of his arm is thin and long, fingers with large nails are longer than the palm. The thumb is pressed to the palm. The index finger is pressed to the middle finger, the ring finger - to the little finger, there is a 30-degree angle between the middle and ring fingers. The man leaned his face to the fingers of his left arm. The hand occupies almost the same area as the man's face, which indicates its equivalent importance. In addition, the contours of the hand, depicted exclusively on the black background of clothes, are clearly delineated, in contrast to the contours of his head that sometimes melt into the background. In general, it is possible to state that the painter deliberately focused attention on the arm with the help of a number of means:

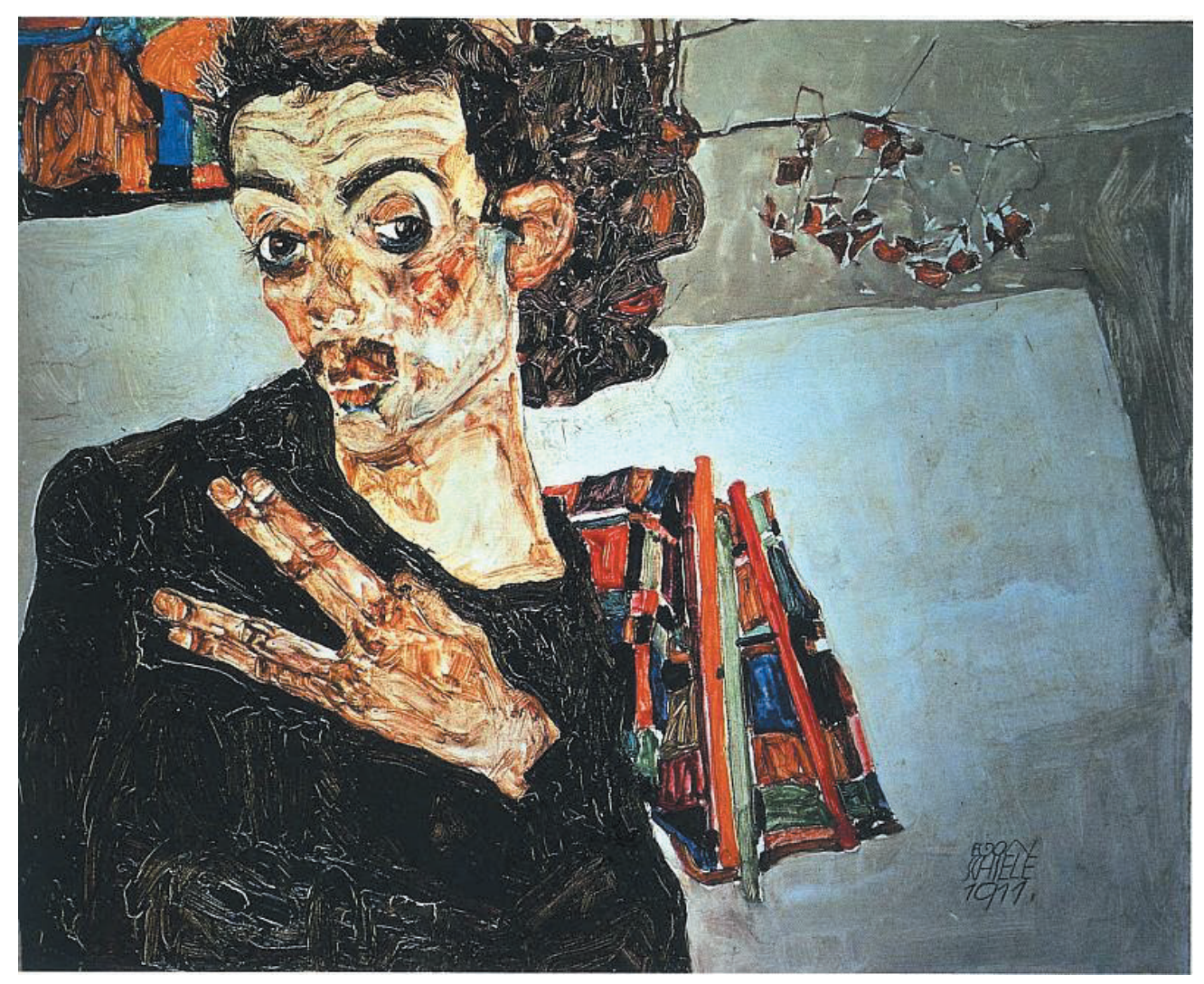

Fig. 1. E. Schiele. Self-Portrait with Black Vase, 1911 
contour, contrast, depicting it at the forefront, a man's head that is bent towards it, and a specific gesture, obviously intended.

The man is depicted in the interior. Most of it is occupied by gray and light gray planes. There is light gray plane right behind the figure, with geometric shapes of various sizes and shapes, including rectangular ones depicted in large strokes with the use of pure colors (red, blue, green, brown, black) on its upper edge to the left of the man. There is a black amorphous vessel to the right of the man's head on the edge of a light gray plane, that is slightly lighter than the man's hair, but almost melting into the hair, and therefore one might think that the hair is not shortly cut, but, on the contrary, long and curly. To the right of the vessel, parallel to the boundary between the gray and light gray planes, there is a branch of a seemingly dry plant with withered brown leaves and red and brown flowers. The space just below the center of the canvas on the light gray plane at the level of the man's sloped left shoulder echoes the upper left corner of the painting - it is composed of rectangular surfaces of pure colors: blue, red, green, maroon, etc., applied with large strokes.

In the self-portrait the artist is, most likely, depicted in his workshop. Light gray planes can initially be mistaken for blank canvases. But location of the black vase at the boundary of the light gray and gray planes rather suggests that a viewer is looking at a tabletop with a vase on it and, probably, some drapery. In this case, it is possible to talk about a violation of the linear perspective, which is generally typical of expressionism. Geometrical rectangular forms of pure colors, concentrated directly behind the artist in the upper left corner of the canvas and at the level of his left shoulder, refer to the works of G. Klimt, although in his works geometric sections were mainly presented in golden and black colors and painted with not so distinct large strokes.

Several questions arose in the process of describing this painting, and an attempt to answer them may lead to its understanding. One of the questions is why did E. Schiele put such a strong emphasis on the hand? And straight away it is worth noting that hands and fingers gestures are emphasized in numerous paintings of this author. Hands, depicted in Schiele's paintings are always disproportionately long and thin, which leads to such concepts as delicacy and fragility. The fact that hands are not in a relaxed state but are always in intended gestures indicates constant and inescapable tension, tension to the fingertips. In Western culture, attention to hands was associated with Christianity - with blessing finger positions. It can be assumed that E. Schiele's emphasis on the arm in Self-Portrait with Black Vase is associated with a hint at the religious mission of art as a whole, and Schiele's art in particular. The painter's hands 
are of particular importance for the creator himself (not only for Schiele, but for the artist in general), they must be in constant connection with thought, in constant tension. It is through the hand in the Self-Portrait that Schiele demonstrates the impossibility of getting out of the creative process even for a moment.

The second question that arises is based on a comparison of the arm and the head in the Self-Portrait: why does the hand stand out so contrastingly against the background of Schiele's clothes, while the boundary between his head (hair) and the vase can hardly be distinguished? After all, from an ordinary point of view, it was easy for the painter to displace the vase to the right and to depict his head on a contrasting gray background. But he chose to do everything exactly this way - the separation of the arm from the background and fusion of the head with the vase. Probably, such a decision suggests that the role of the arm in the creative process is like nothing else. The head is a vase, a repository, and it is not always full of fresh ideas and thoughts (there are faded branches in the vase). In addition, the head in the painting is leaned, it clings to the arm, which indicates the greater importance of inspiration, which moves the hand, as compared with the thoughts that fill the head.

The third question is: why did the artist devote about half of the space to himself in the Self-Portrait, giving the rest of it to the image of the interior and, in addition to that, shifting himself from the main axis? It can be explained by the idea that the role of the painter and the author himself is not central and dominant in art; the painter's environment, including the studio and teachers, even not current ones, but those who are still with the painter (references to G. Klimt through the multi-colored areas of the painting) are of the same importance.

The Holy Family, 1913. Private collection (Fig. 2)

Three people are depicted in the painting of a vertical format. In the lower part of the painting a small and childishly round face of Christ and two hands with spread fingers are depicted in a triangular shape with rounded corners. The face is not clearly traced, only eyes, nose and mouth are drawn vaguely. It is not clear whether the eyes are open or closed, due to the fact that the triangular shape is several times crossed by horizontal and diagonal lines, two of which are drawn at the level of the child's eyes.

The triangular shape with the face and hands inside is placed againtst a dark brown background formed by the shapeless clothes of the female character - Mary. The woman is represented in a strong lean to the left, her head touches the left vertical edge of the painting. With her right hand with thin, long and widely spread fingers, the woman supports the triangular form with the child inside from the bottom and one 


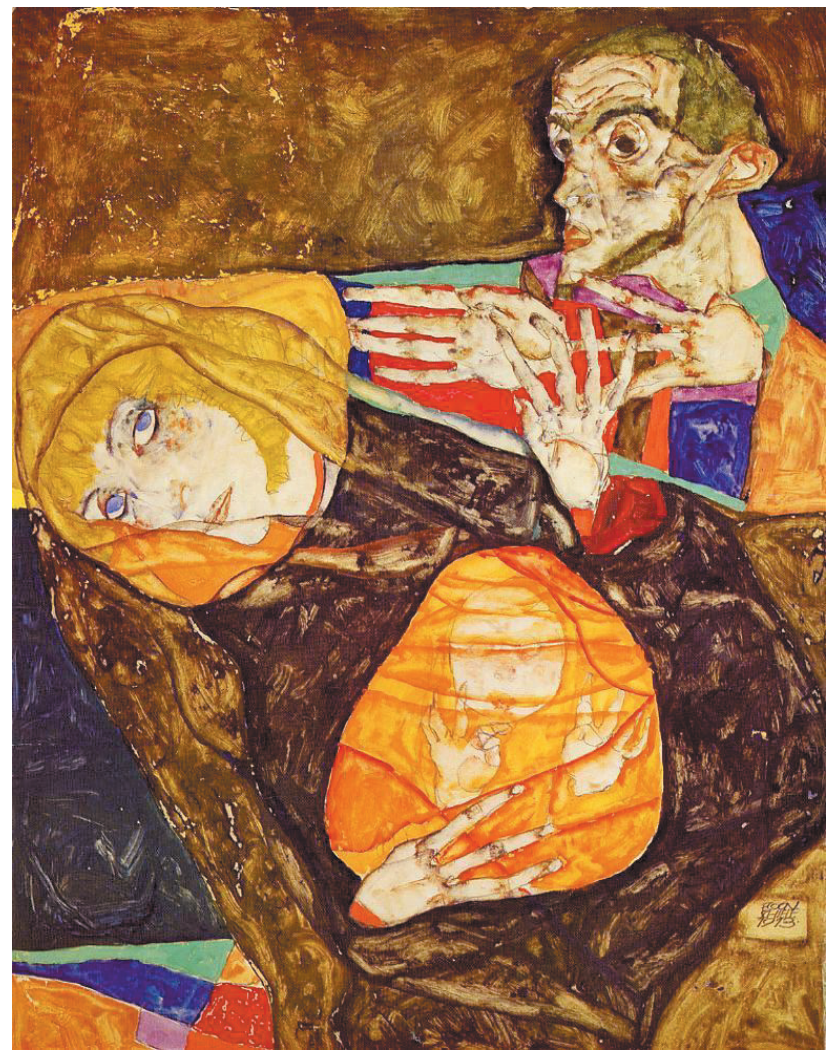

Fig. 2. E. Schiele. The Holy Family, 1913

side. Her left hand is turned up, four fingers are spread apart, the thumb is pressed to the palm and the bottom of the index finger. The palm and fingers of the left hand are beyond the woman's contours.

In the upper right corner of the painting there is a man, Joseph, who is behind the woman with the child. The man's hands are positioned horizontally, the fingers are turned in the direction from the right edge of the canvas to its center, and they are very tense. The hand of his right arm and the fingers of the left hand are crossed on the top by the fingers of the woman's left hand. The man wears clothes of fabric with rectangular shapes of different pure colors: blue, green, red, brown, etc. The same fabric with separate rectangular multi-colored fragments can be seen in the lower left corner of the canvas.

The spaces of the painting filled with multi-colored rectangular forms refer to the abovementioned Self-Portrait and to the works of G. Klimt. The very image of Joseph refers to Klimt, to be more precise, to the painting of E. Schiele dated the same 1913 - Klimt in a Light Blue Smock (Fig. 3). On this drawing, there is a man in the 


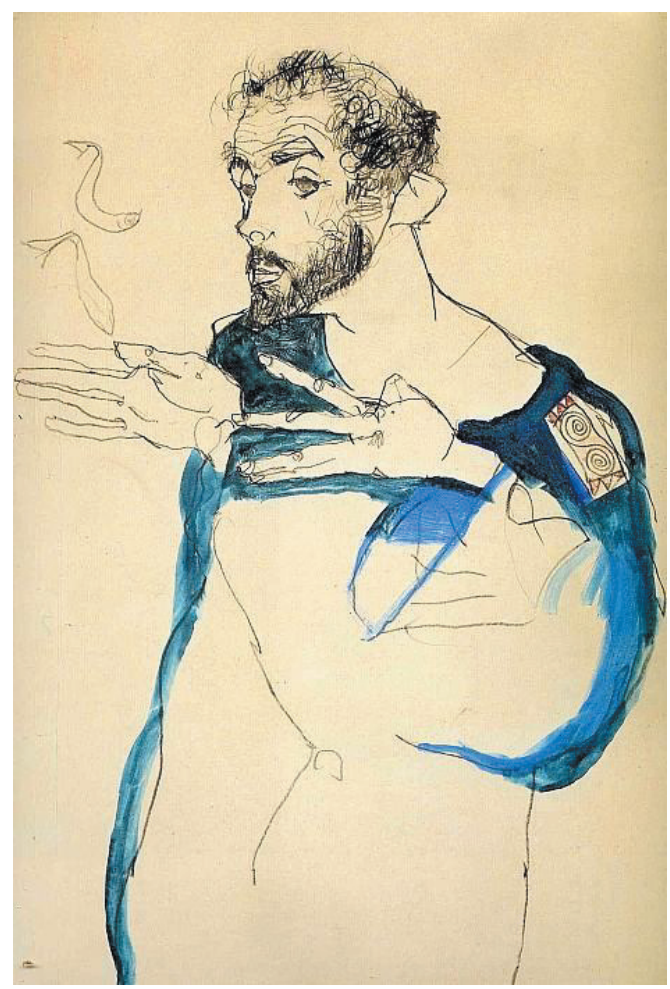

Fig. 3. E. Schiele. Klimt in a Light Blue Smock, 1913

same pose and with the same hand gestures as in The Holy Family. This portrait of Klimt confirms the idea that the colorful fabric in the abovementioned canvases by E. Schiele can refer to one of the founders of the Vienna Secession. It is Klimt who is Joseph, Mary's betrothed and Christ's adoptive father. The woman in The Holy Family has a portrait resemblance to Wally Neuzil, the model and the muse of E. Schiele. In general, it is possible to say that in this case Schiele himself is the infant Mary is carrying. Then the viewer sees the self-portrait of Schiele's essence, as well as portraits of those who had the greatest influence on his development, basically, the parents of his talent (Klimt and Neuzil), and the portrait of the most divine essence of art embodied in E. Schiele. Klimt is depicted in the background of the painting. Basically, he is the basis and protection of both his family and Schiele's creative path, and Neuzil binds him with Schiele with the help of her hands: one hand covers the hands of JosephKlimt, and the other one supports the infant Christ-Schiele. It is interesting that the baby is still in membranes, not born yet, moreover, not able to see yet (the lines that cross his eyes). Consequently, Schiele assumes that his talent had not really opened yet, had not manifested itself in this world. 
Death and the Maiden, 1915. 150 x $180 \mathrm{~cm}$. Oil on canvas. Galerie Belvedere, Vienna, Austria (Fig. 4)

In the central part of the horizontal painting there are two figures - a man and a woman. The woman occupies a central position in the painting. Her body is placed diagonally from the lower right corner of the painting to the upper left one. She is dressed in a colorful dress with predominating red color, that is above her knees with short sleeves and zigzag hem. Pale skin of the woman, depicted in white and brown colors, contrasts with her dress; her cheeks are brightly blushed and bright red lips are highlighted on her face. The woman has short light brown hair, almost completely covering her eyes, and barely visible look of her eyes is directed to the viewer. The woman is barefoot, she leans on her knees. Her long arms embrace the man's torso under his arms. Her index fingers are rounded and form a lock behind the man's back. Being in an unstable position, the woman has three points of support: her knees and the man, whose chest she clings her head to and who she embraces with her hands.

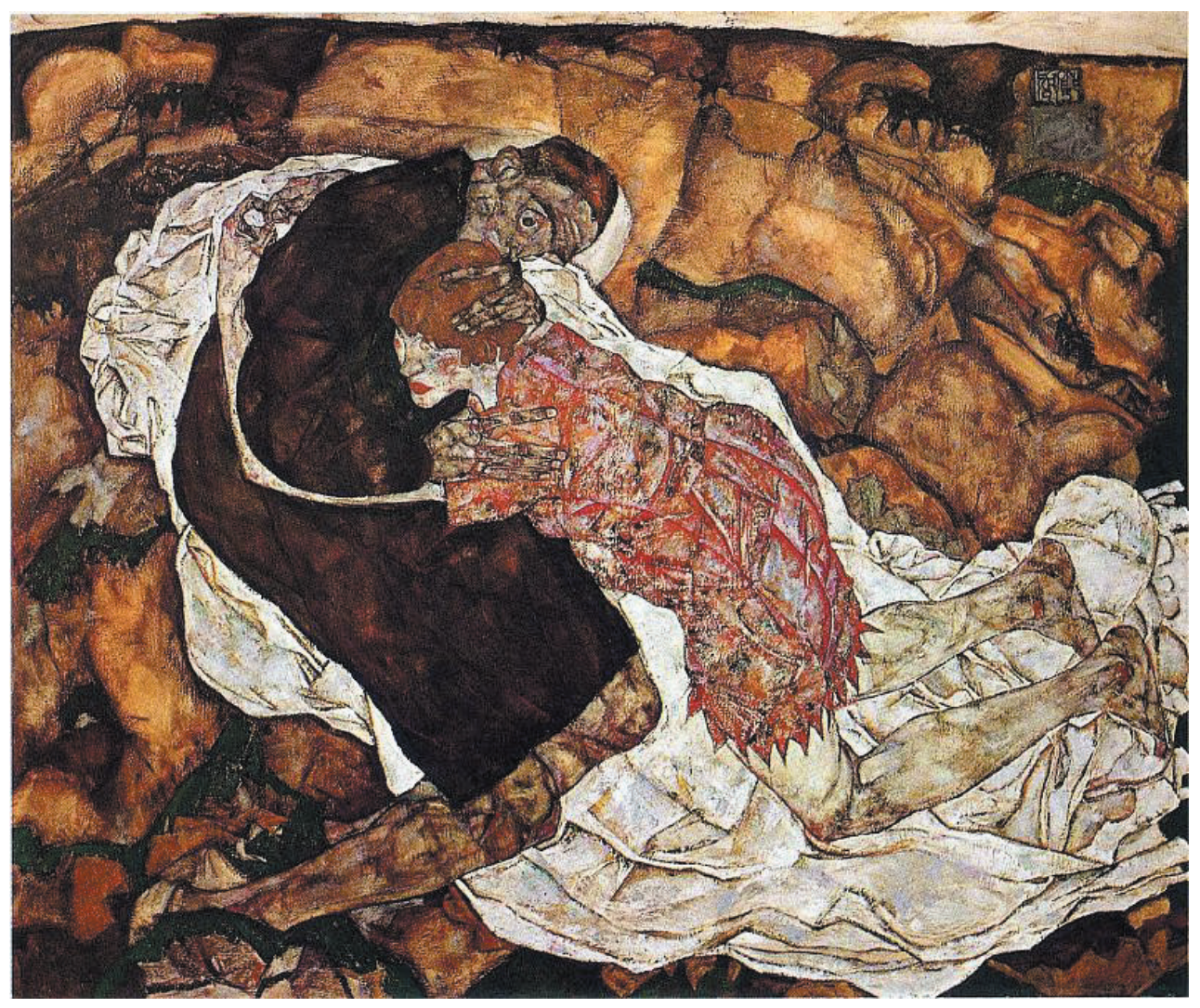

Fig. 4. Death and the Maiden, 1915 
The man is also depicted on his knees, but his figure is placed almost vertically, but not diagonally. Although it is necessary to make a reservation: the man's figure is not depicted in a straight manner, it is a large S-shaped zigzag with two bends. It is possible to say that the zigzag line is virtually the basic one in the image of human figures: it is not only the man's pose and the hem of the dress, since the woman is also a zigzag formed by her feet, angle of her heels, ankles, angle of her knees, her hips, pelvic angle, back and shoulder, elbow angle and her forearm.

The man, as well as the woman, is barefoot, his skin is painted with a much greater use of brown. The man's face is depicted almost in profile, the viewer can only see his big right eye, the look of his eye is unfocused and directed downwards. The man's head is bent to the head of the woman, he touches her hair with his chin and lips. The man is dressed in dark brown knee-length clothes with long sleeves. The hand of his right arm covers the left shoulder of the woman: the thumb is from the side of her chest; four other fingers are from the side of her back. The little finger, as well as ring and middle fingers are connected, the index finger is depicted separately. The hand of his left arm covers the back of the woman's head, the fingers are arranged in the same way as fingers of the right hand: three fingers together, the index finger separately, and the thumb is not visible.

The way the figures are merged and blended in the upper part, the way they complement each other turning into a single whole, and the extent they are split in opposite directions downwards, although they continue to complement zigzag lines of each other, make us refer to the title of the painting — Death and the Maiden, in order to understand what is the force that separates and breaks the link that seems so strong. That is, the viewer sees not the result (both characters are alive), but the process of death itself. The process that separates the living, robbing one from the other, depriving integrity and stability despite all the efforts (the woman's fingers that form a lock, and tightly embracing each other main characters). The woman has a greater degree of stability: while the figure of the man curved as a zigzag retains its vertical pose, the woman is depicted diagonally, and this is the "diagonal of defeat" - from the right to the left upwards. The diagonal of defeat is also intensified by the background on which the figures are depicted; this is a very big and white cloth in deep textured folds. The woman's contours do not extend the cloth's boundaries, while most of the man's head and his legs below the knees are outside the cloth. Brown amorphous forms with dark brown crooked boundaries between them and rare green patches are depicted outside the cloth. 
And yet, despite the lesser stability of the female character, the title of the painting remains unclear. If the viewer sees the process of dying and death coming, and Death is the main character (Death and the Maiden), then is it about death of the Maiden? If we take this assumption as a correct one, then the viewer sees dying of the female character losing her stability (in this case, vital power), trying to hold on to the man with her last bit of strength (leans on him, embracing him tightly, locking fingers behind his back). The man, in this case, is only a weak, temporary support, with whom the woman is separated by death.

But there might be another interpretation of the title. It is inspired by the earthy color of the man's skin, his vacant and defocused look, the fact that his contours extend beyond the cloth to the zone of brown, stony background, as well as his dark brown, stony clothes and wary look of the woman. All these elements can be synthesized as the fact that it is the man who is dying, he accepted this fact, and the woman sullenly sees death approaching. In this case, the title of the painting suggests that the Maiden is fighting against death, not against her own death, but the man's one, trying not to let him go, holding him as strong as she can, losing her balance. But the man looks like a stone, almost lifeless.

But there is also a third interpretation, based on the fact that in the German language death (der Tod) is masculine. In this case, the viewer sees not just dying of one of the two characters, separating their former unity and integrity, but the embrace of Death the woman is subjected to, she does not oppose to it but, on the contrary, searches for her balance in it.

The appeal to the portrait similarity of the man to E. Schiele himself, and the women to W. Neuzil (represented as Mary in the abovementioned painting The Holy Family) does not clarify the situation with which version of the title's interpretations is the most adequate due to the fact that the year of the painting creation - 1915 - is the year when Schiele broke with Neuzil, that can be considered as both death of one of them and the reaction to it of the other one, and as the fact that having been the initiator of their break, Schiele became death for Neuzil, although in the painting created just two years before that, it was Wally who acted as the Mother, and the Holy Mother of Schiele himself.

\section{Conclusion}

The three paintings under study can be combined into one series, demonstrating the genesis of Egon Schiele's ideas about art in general and about his creative work in particular. 
The main author's ideas about art are presented in Self-Portrait with Black Vase. There is a hint to the religious mission of art in this painting, embodied, in particular, by the hands of the painter, that must always be in tension to their fingertips. It is through his hand that Schiele demonstrates the impossibility of giving up creative process even for a moment. The role of the hand in the creative process is like nothing else. The head is a vase, a repository, and it is not always full of fresh ideas. In addition, the painting contains the evidence that inspiration that moves the hand is more significant, than the thoughts that fill the head. The role of the painter himself is not central and dominant in art; the painter's environment, including the studio and teachers, even not current ones, but those who are still with the painter, is also important.

In the painting dated 1913, E. Schiele interprets his and G. Klimt's missions in art. G. Klimt is given the role of the adoptive father, an earthly mentor for Schiele's divine talent, that has not manifested itself fully and has not seen the light yet, but is awaiting for its present existence, which it will also gain through his muse and model W. Neuzil. That is, this painting develops the idea about who and how influences the formation of art, and continues the idea about the divinity of the essence of E. Schiele's art.

The painting of 1915 is permeated with the spirit of tragedy both at the level of quite a dark color palette and the main compositional lines. The presence of G. Klimt is not felt in this painting, it is set aside under the influence of the trouble E. Schiele and $W$. Neuzil faced directly. This trouble is death, which in this painting can be interpreted in several ways. First, it depicts the very process of dying, separating two people who lose their integrity and stability. Secondly, death comes to the woman who is trying to resist it as much as she can, tightly embracing the man. Thirdly, death almost captured the man turning him into a stone, and the woman tries to protect him from that. Fourthly, the man, E. Schiele as the initiator of their break, is death for the woman.

But in the latter case, the death of the woman turns out to be death for Schiele-Death himself from the creative standpoint, and this premonition fills the painting with tragic spirit. In other words, even the divine essence of E. Schiele's talent, most likely, will not be able to resist death caused by the break initiated by Schiele himself.

\section{References}

Aguado, C.I. (2011). Mother with Two Children. Egon Schiele, 1917. In Pediatria de Atencion Primaria, 13(49), 148.

Barker, G. (2003). Schiele Townscape, Gauguin Landscape Stand Out at Summer Sales. In Artnews, 102(8), 76. 
Blackshaw, G. (2007). The Pathological Body: Modernist Strategising in Egon Schiele's Self-Portraiture. In Oxford Art Journal, 30(3), 377-401.

Borowitz, H.O. (1974). Youth as Metaphor and Image in Wedekind, Kokoschka, and Schiele. In Art Journal, 33(3), 219-225.

Brabenec, S.E. (2001). The Art of Determining “Stolen Property:” United States v. Portrait of Wally, a Painting by Egon Schiele, 105 F. supp. 2D288 (S.D.N.Y. 2000). In University of Cincinnati Law Review, 69(4), 1369-1400.

Bralkova, A.V., Gerasimova, A.A., Govoruhina, Yu.A., Grigor'eva, T. Yu., Gur'yanova, V.A., Zhukovskij, V.I., Karlova, O.A., \& Kistova A. V. (2015). Novaia artkritika na beregakh Eniseia [New Art Critic on the Banks of the Yenisei]. Krasnoyarsk.

Buckley, P.J. (2012). Gustav Klimt, Egon Schiele, and fin de siècle Vienna. In American Journal of Psychiatry, 169(7), 692.

Bueno, S., Pilar, M. (2012). Egon Schiele: Museo Guggenheim. Bilbao. In AACADigital: Revista de la Asociación Aragonesa de Críticos de Arte, 21.

De Oliveira, D.F. (2012). Egon Schiele as Trickster: Possible Approaches. In Visualidades, 10(2), 159-177.

Erbguth, F.J. (2010). Egon Schiele and Dystonia. In Frontiers of Neurology and Neuroscience, 27, 46-60.

Heller, R. (1977). Recent Scholarship on Vienna's “Golden Age," Gustav Klimt, and Egon Schiele. In The Art Bulletin, 59(1), 111-118.

Izenberg, G.N. (2006). Egon Schiele: Expressionist Art and Masculine Crisis. In Psychoanalytic Inquiry, 26(3), 462-483.

Karagoda, K.P. (2016). "Smert' zhenshchiny" v literature i iskusstve XIX-XX vV. ["The Death of a Woman" in Literature and Art of the $19^{\text {th }}-20^{\text {th }}$ Centuries]. In Obshchestvo: filosofiya, istoriya, kul'tura [Society: Philosophy, History, Culture], 6.

Kharseyeva, N.V., Godal, A.N. (2017). Estetizatsiia psikhicheskikh patologii kak khudozhestvennyi fenomen (na primere tvorchestva Egona Shile i Khansa Bellmera) [Aestheticization of Mental Pathologies as an Artistic Phenomenon (by case study of the works of Egon Schiele and Hans Bellmer)]. In Obshchestvo: filosofiya, istoriya, kul'tura [Society: Philosophy, History, Culture], 7.

Kistova, A.V., Pimenova, N.N., Bukova, M.I. (2018). Sovremennoe sostoianie dekorativno-prikladnogo iskusstva evenkov — korennykh narodov Sibirskoi Arktiki [The Current State of the Arts and Crafts of the Evenks, the Indigenous Peoples of the Siberian Arctic]. In Severnye arkhivy i ekspeditsii [Northern Archives and Expeditions], 2(1), 49-56. 
Kistova, A.V., Tamarovskaya, A.N. Architectural Space as a Factor of Regional Cultural Identity. In Journal of Siberian Federal University. Humanities \& Social Sciences, 4 (2015), 735-749.

Kistova, A.V., Muzhuhoeva, M.M., Koptyakov, YU. B., Titovskii, A.L. (2016). Ispol'zovanie imeni Vasiliya Ivanovicha Surikova v konstruirovanii polozhitel'nogo obraza goroda Krasnoiarska [Using the Name of Vasily Ivanovich Surikov in Making a Positive Image of the City of Krasnoyarsk]. In NB: Administrativnoe pravo i praktika administrirovaniya [NB: Administrative Law and Administration Practice], (6), 1-13.

Kistova, A.V., Zamaraeva, J.S., Pimenova, N.N., Reznikova, K.V., Koptseva, N.P., Seredkina, N.N. (2016). Regional Peculiarities in Modernization Processes within the Territories of Central Siberia. In International Review of Management and Marketing, 6(4), 857-865.

Knafo, D. (1991). Egon Schiele and Frida Kahlo: The Self-Portrait as Mirror. In Journal of the American Academy of Psychoanalysis, 19(4), 630-647.

Kolesnik, M.A. (2016). Konstruirovanie russkoi kul'turnoi identichnosti (kontseptual'nyi i metodologicheskii podkhody) [Construction of Russian Cultural Identity (Conceptual and Methodological Approaches)]. In Avtoreferat dissertatsii kandidata kul'turologii [Abstract of the Dissertation of the Candidate of Cultural Sciences]. Krasnoyarsk.

Kolesnik, M.A., Libakova, N.M., Sertakova, E.A. (2018). Art Education as a Way of Preserving the Traditional Ethnocultural Identity of Indigenous Minority Peoples from the North, Siberia and the Far East. In Novosibirsk State Pedagogical University Bulletin, 8 (4), 233-247.

Koptseva, N.P., Reznikova, K.V. (2014). Filosofskie osnovaniia khudozhestvennogo tvorchestva Al'bera-Sharlia Lebura ("Ruanskaya shkola" frantsuzskogo impressionizma) [The Philosophical Foundations of the Art of Albert-Charles Lebourg ("Rouen School" of French Impressionism)], In Filologiia: nauchnye issledovaniia [Philology: Scientific Research], 1, 77-92.

Koptseva, N.P., Reznikova, K.V. (2015). Tri kartiny Zdislava Beksinski: kak vozmozhno iskusstvo "posle Osventsima" [Three Paintings by Zdzislaw Beksinski: How Art is Possible "after Auschwitz"]. In Vestnik Tomskogo gosudarstvennogo universiteta [Tomsk State University Journal], 400, 121-133.

Koptseva, N.P., Reznikova, K.V. (2017). The Cultural Aspects of Advertising Communications in Modern China. In East Asia: An International Quarterly, 34(4), 249-269. 
Koptseva, N.P., Reznikova, K.V. (2018). The Construction of Cultural and Religious Identities in the Temple Architecture. In Journal of Siberian Federal University. Humanities \& Social Sciences, 7(11), 1021-1082.

Koptseva, N.P., Zhukovskiy, V.I. (2008). The Artistic Image as a Process and Result of Game Relations between a Work of Visual Art as an Object and its Spectator. In Journal of Siberian Federal University. Humanities \& Social Sciences, 2(1), 226-244.

Lam, S.M. (2003). Egon Schiele: Expressive sensuality. In Archives of Facial Plastic Surgery, 5(2), 212-213.

Leshchinskaya, N.M., Petrova, K.I. (2019). Dekorativno-prikladnoe iskusstvo korennykh malochislennykh narodov Severa Krasnoyarskogo kraia: kostoreznoe iskusstvo [Decorative and Applied Art of Indigenous Peoples of the North of the Krasnoyarsk Territory: Bone Carving]. In Severnye Arhivy i Ekspedicii [Northern Archives and Expeditions], 3 (1), 72-79.

Libakova, N.M., Kolesnik, M.A., Sergeeva, N.A., Sertakova E.A. (2017). Issledovatel'skie vozmozhnosti antropologii iskusstva na primere kostoreznykh proizvedenii masterov Sibiri [Research Opportunities of the Anthropology of Art Exemplified by Bone Carving Works of the Masters of Siberia]. In Sibirskii antropologicheskii zhurnal [Siberian Journal of Anthropology], 1 (06), 22-34.

Lozinskaya, V.P. (2018). Franz Joseph Haydn. "The Seven Last Words of Our Saviour on the Cross" Oratorio. In Journal of Siberian Federal University. Humanities \& Social Sciences, 11(9), 1425-1439. DOI: 10.17516/1997-1370-0313

Metlyaeva, S.V. (2017). Kul'turnaia tsennost' muzykal'no-ispolnitel'skikh osobennostei kompozitora [Cultural Value of the Composer's Musical and Performing Features]. In Sibirskii antropologicheskii zhurnal [Siberian Journal of Anthropology], 4 (12),13-20.

Resnik, S. (2000). The Hands of Egon Schiele. In International Forum of Psychoanalysis, 9(1-2), 113-123.

Reznikova, K., Seredkina, N., Koptseva, N., Zamaraeva, J. (2016). Regional Specifics of Social Values and Their Impact on Central Siberian Territories' Modernization (Based on Research of Krasnoyarsk Region). In Economic Annals-XXI, 160(7-8), 92-95.

Seredkina, N.N. (2015). Cultural and Semiotic Strategies of Constructing Indigenous Northern Ethnicity in Art (Based on the Yakut Art School). In Journal of Siberian Federal University. Humanities \& Social Sciences, 4 (8), 769-792.

Sitnikova, A.A., Zhukovskiy, V.I. (2018). Visualization of the Concept of State in the Architecture of the Moscow Cathedral of the Intercession on the Moat (1555-1561). 
In Journal of Siberian Federal University. Humanities \& Social Sciences, 9(11), 15131528.

Smith, K.A. (2000). Egon Schiele's Treescapes. Work and World: Unframing the autonomous landscape. In Art History, 23(2), 233-261.

Vittori, G. (2018). Choreographing Expressionist Paintings: Claudia Contin Arlecchino Dances Egon Schiele. In Dance Chronicle, 41(2), 212-238.

Zhukovskiy, V.I. (2008). The Visual Content in Representative Paintings of Andrei Pozdeev. In Journal of Siberian Federal University. Humanities \& Social Sciences, 1, 124-148.

Zhukovskiy, V.I. (2014). Modern Theory of Visual Art: Regional Project. In Journal of Siberian Federal University. Humanities \& Social Sciences, 8(7), 1301-1311.

Zhukovskiy, V.I., Pivovarov, D.V. (2008). The Nature of Visual Thinking. In Journal of Siberian Federal University. Humanities \& Social Sciences, 1, 149-158.

Zhukovskiy, V.I., Pivovarov, D.V. (2012). The Religious-Artistic Image of a Perfect Human Integrity: A. A. Ivanov's Picture "The Appearance of Christ Before People". In Journal of Siberian Federal University. Humanities \& Social Sciences, 1(5), 48-55.

\title{
Три картины Эгона Шиле: представления о сущности искусства
}

\author{
К.В. Резникова, А.А. Ситникова, Ю.С. Замараева \\ Сибирский федеральный университет \\ Россия, 660041, Красноярск, пр. Свободный, 79
}

\begin{abstract}
Эгон Шиле (1890-1918) является одним из наиболее значимых представителей австрийского экспрессионизма, чьи работы повлияли не только на многих живописиев и графиков, но также и на танцоров, театральных деятелей. При этом творчеству Э. Шиле посвящено немного академических публикаций, а среди имеющихся значительную долю составляют те, в которых его работы рассматриваются как свидетельства отклонений в психическом здоровье художника. В качестве основного метода настоящей работы выступает философско-искусствоведческий анализ, апеллирующий к общечеловеческим смыслам произведений. Материалом для исследования стали три живописных полотна: «Автопортрет с черным керамическим сосудом» (1911), «Святое семейство» (1913) и «Смерть и девушка» (1915), которые можно объединить в одну серию, демонстрирующую генезис представлений Эгона Шиле об искусстве в целом и о своем творчестве в частности.
\end{abstract}

Ключевые слова: Эгон Шиле, экспрессионизм, рубеж XIX-ХХ вв., Г. Климт, Вена, автоnopmpem.

Научная специальность: 24.00.01 - теория и история культуры. 